\title{
Surface water as a cause of land degradation from dryland salinity
}

\author{
J. Nikolaus Callow ${ }^{1,2}$, Matthew R. Hipsey ${ }^{1}$, and Ryan I. J. Vogwill ${ }^{3}$ \\ ${ }^{1}$ UWA School of Agriculture and Environment, The University of Western Australia, \\ 35 Stirling Highway, Crawley, Perth, Western Australia, 6009, Australia \\ ${ }^{2}$ Department of Geography, The University of Western Australia, \\ 35 Stirling Highway, Crawley, Perth, Western Australia, 6009, Australia \\ ${ }^{3}$ Hydro Geo Enviro Pty Ltd, Carine, Western Australia, 6020, Australia
}

Correspondence: J. Nikolaus Callow (nik.callow@uwa.edu.au)

Received: 2 August 2019 - Discussion started: 23 August 2019

Revised: 20 December 2019 - Accepted: 9 January 2020 - Published: 17 February 2020

\begin{abstract}
Secondary dryland salinity is a global land degradation issue. Drylands are often less developed, less well instrumented and less well understood, requiring us to adapt and impose understanding from different hydrogeomorphological settings that are better instrumented and understood. Conceptual models of secondary dryland salinity, from wet and more hydrologically connected landscapes imposed with adjustments for rainfall and streamflow, have led to the pervasive understanding that land clearing alters water balance in favour of increased infiltration and rising groundwater that bring salts to the surface.

This paper presents data from an intra-catchment surface flow gauging network run for 6 years and a surface-watergroundwater (SW-GW) interaction site to assess the adequacy of our conceptual understanding of secondary dryland salinity in environments with low gradients and runoff yield. The aim is to (re-)conceptualise pathways of water and salt redistribution in dryland landscapes and to investigate the role that surface water flows and connectivity plays in land degradation from salinity in low-gradient drylands. Based on the long-term end-of-catchment gauge, average annual runoff yield is only $0.14 \%$ of rainfall. The internal gauging network that operated from 2007-2012 found pulses of internal water (also mobilising salt) in years when no flow was recorded at the catchment outlet. Data from a surfacewater-groundwater interaction site show top-down recharge of surface water early in the water year that transitions to a bottom-up system of discharge later in the water year. This connection provides a mechanism for the vertical diffusion of salts to the surface waters, followed by evapo-concentration and downstream export when depression storage thresholds
\end{abstract}

are exceeded. Intervention in this landscape by constructing a broad-based channel to address these processes resulted in a $25 \%$ increase in flow volume and a $20 \%$ reduction in salinity by allowing the lower catchment to more effectively support bypassing of the storages in the lower landscape that would otherwise retain water and allow salt to accumulate.

Results from this study suggest catchment internal redistribution of relatively fresh runoff onto the valley floor is a major contributor to the development of secondary dryland salinity. Seasonally inundated areas are subject to significant transmission losses and drive processes of vertical salt mobility. These surface flow and connectivity processes are not only acting in isolation to cause secondary salinity but are also interacting with groundwater systems responding to land clearing and processes recognised in the more conventional understanding of hillslope recharge and groundwater discharge. The study landscape appears to have three functional hydrological components: upland, hillslope "flow" landscapes that generate fresh runoff; valley floor "fill" landscapes with high transmission losses and poor flow connectivity controlled by the micro-topography that promotes a surface-groundwater connection and salt movement; and the downstream "flood" landscapes, where flows are recorded only when internal storages (fill landscapes) are exceeded. This work highlights the role of surface water processes as a contributor to land degradation by dryland salinity in low-gradient landscapes. 


\section{Introduction}

Secondary dryland salinity is a severe land degradation problem caused where land clearing alters the hydrological balance and rising saline groundwater degrades surface water resources and soils. Secondary dryland salinity (herein "salinity") is a global issue reported in North America, central and southern Africa, Australia, South America, central and northern China, the Middle East, and central Asia (Ghassemi et al., 1995; Callow and Clifton, 2011). It is found in landscapes cleared for agriculture, where past marine conditions have left saline deposits or salts originating as an oceanic aerosol have accumulated in the soils and the groundwater (Callow and Clifton, 2011; Ghassemi et al., 1995; Hingston and Gailitis, 1976). Over 30\%-40\% of some landscapes can be affected (Ferdowsian et al., 1996), impacting infrastructure, agricultural production and biodiversity (Cramer and Hobbs, 2002; Callow, 2012; Pannell, 2001). Planning of adaptation and mitigation strategies to address the negative impacts of salinity requires a sound conceptual understanding such that management interventions can address causal processes of salt redistribution and accumulation in the landscape.

Drylands occupy something of a midpoint along a hydrological spectrum between wet and hydrologically connected landscapes and dry poorly connected landscapes. Hydrologically connected temperate, sub-tropical and tropical catchments have higher and more reliable rainfall, are well studied and better instrumented and can support irrigated and seasonal rain-fed agriculture. At the other end are sparsely populated and poorly instrumented flat and semi-arid "smooth plainlands", rangelands and areas grading to a desert, where rainfall is too low or unreliable to support seasonal agriculture. The paucity of both hydrological data and detailed hydrological process studies in drylands means that our conceptual understanding of dryland systems has often been transposed from the more intensively studied and instrumented temperate and wet sub-tropical systems (Bracken and Croke, 2007; Bracken et al., 2013). This approach presumes that the interplay of hydrological processes are functionally similar such that surface and groundwater fluxes and water balance partitioning can be inferred by scaling to the available precipitation and streamflow data. The concept of water balance still holds in drylands, with lower rainfall and runoff and accounting for groundwater recharge, balanced by greater evapotranspiration (ET) potential (Thornes, 2009; Knighton and Nanson, 2001; Tooth, 2000; McMillan et al., 2011). Bracken et al. (2013) commented on the need for a better conceptual understanding of hydrological processes and connectivity that shape dryland catchments to allow catchment managers to know where, when and how to manage adverse hydrological processes and landscape degradation. This is a particularly acute problem in the world's dryland catchments impacted by salinity. The aim of this paper is to firstly review the past conceptual basis for how land clearing impacts salin- isation processes in dryland catchments and then to present a dataset from a catchment in Western Australia that highlights the complexity of surface water flows in shaping water and salt redistribution and export. The findings from the dataset are used to reconceptualise the spatial and temporal variability in hydrologic pathways, which can be used to inform improved land management practice.

\section{Historical basis for conceptual models of dryland salinity}

\subsection{Dryland hydrological processes}

Drylands are notable for a long history of land degradation challenges related to the disturbance of hydrological balance, resulting in issues such as desertification and salinity, with severe impacts on civilisations as far back as the Mesopotamian empire (Conacher and Conacher, 1995; Conacher and Sala, 1998). The less predictable nature of rainfall and runoff, high levels of socio-economic disadvantage and population growth and hydrological data paucity mean that drylands are under-developed in terms of hydrological infrastructure and conceptual understanding and are sites of water vulnerability (Koohafkan and Stewart, 2008). Their predominantly mid-latitude location is notable as a region recognised as vulnerable to a future climate projected to have declining surface and groundwater resources (Barron et al., 2012; Smettem and Callow, 2014; Smettem et al., 2013; McFarlane et al., 2012). Attempts to identify a clear classification and understanding of dryland hydrology have been discussed, with landscape properties and runoff regimes highlighted as potential key determinants of hydrology (Wagener et al., 2007; McDonnell and Woods, 2004). Hydrological data scarcity, more limited process knowledge and variable hydrological regime present profound challenges to managing hydrological processes and land degradation including by salinity in the world's drylands.

Drylands are influenced by processes such as antecedent conditions and seasonal rainfall accumulation that drive saturation excess from a partially contributing variable source area, similar to wetter and more temperate and tropical areas (Ruprecht and Schofield, 1989; Ruprecht and Stoneman, 1993). They are also influenced by infiltration excess (Hortonian) processes, event and episodic flow regimes, and limited hydrological connectivity with high transmission losses, typical of drier, semi-arid landscapes (Koohafkan and Stewart, 2008; Nanson et al., 2002; Powell, 2009; Tooth, 2000; Walker et al., 1995; Bracken and Croke, 2007; Bracken et al., 2013). Work on improving hydrological understanding and prediction in data-scarce basins has emphasised the importance of understanding threshold behaviour including activation and deactivation of dynamic (surface and subsurface) drainage networks and landscape specific emergent be- 
haviours that can override small-scale processes (Hrachowitz et al., 2013).

Themes that emerge from the limited research on hydrological processes in the world's drylands highlight the significant role of processes related to water connectivity, including the lateral and longitudinal hydrological redistribution of surface water and surface-groundwater interactions, including in work from northeastern Brazil (Costa et al., 2012), Africa (Bonell and Williams, 2009; Bauer et al., 2006) and Spain (Abrisqueta et al., 2007; Ceballos and Schnabel, 1998; Nicolau et al., 1996). Ecohydrology and the interaction of vegetation with rainfall, topography, aquifers and runoff is also highlighted as significant (Ludwig and Tongway, 2000; Ludwig et al., 1997, 2005; Wilcox and Newman, 2005; Gifford, 1978; Callow, 2011; Eamus et al., 2006; Turnbull et al., 2012; Wang et al., 2012). Topographic subtleties are disproportionately important in low-gradient drylands as microtopography from the Earth's surface, but also organic processes such as animal workings, woody debris, rocks and litter debris dams can have a significant influence on hydrological and biogeochemical pathways (Ludwig et al., 2005; Wilcox and Newman, 2005). Micro-scale processes and vegetation-hydrology-topography interactions are also recognised as particularly significant (Dunkerley, 2011; Ludwig et al., 2005; McGrath et al., 2012; HilleRisLambers et al., 2001). The trigger-transfer-reserve-pulse (TTRP) framework of Ludwig et al. (1997) and Ludwig and Tongway (2000) emphasises the role of microtopography in the form of litter dams (Ludwig et al., 2005) that controls patterns of water redistribution and longitudinal connectivity due to a high depression storage of "runon" water. Bartley et al. (2006) demonstrated the interaction of hydrological, geomorphological and ecological processes across multiple scales control runoff and erosion in the semi-arid rangelands.

\subsection{Hydrological processes causing dryland salinity}

Native vegetation systems of the world's drylands have been extensively cleared for agricultural development. Deeprooted vegetation has been replaced with seasonal cropping and pasture and shifted hydrology towards increased runoff and groundwater recharge (Callow and Smettem, 2007; Commander et al., 2001; Ruprecht and Schofield, 1991; Muirden et al., 2003). In the study region, annual and peak flood discharge increased by a factor of 2-4 times (Muirden et al., 2003; Pen, 1999; Callow and Smettem, 2007; Bowman and Ruprecht, 2000); groundwater recharge increased by 530 times $\left(0.02-0.14 \mathrm{~mm} \mathrm{yr}^{-1}\right.$ under native woodland systems to 6-30 $\mathrm{mm} \mathrm{yr}^{-1}$ with agriculture) (George, 1992; George and Conacher, 1993); and groundwater levels have risen by up to tens of metres (Bennett and George, 2008; Callow and Smettem, 2007; George and Conacher, 1993), expanding the saturated, shallow groundwater areas and other partial-source areas (Ruprecht and Schofield, 1989, 1991; Ruprecht and Stoneman, 1993). Responses of water resources and biodi- versity to the resultant increase in landscape salinisation have been reported for over a century (Bennett and Macpherson, 2002; Callow and Smettem, 2007; Halse et al., 2003; Nielsen et al., 2003; Peck and Hatton, 2003; Mann, 1907; Wood, 1924; Wood and Wilsmore, 1928).

\subsubsection{Hillslope recharge model}

The association of salinity and land clearing was recognised from the first decade of the twentieth century, associated with impacts on water resources used for railway locomotives (Mann, 1907). Wood (1924) reported that "where destruction of the native vegetation has taken place rapidly, there has followed a very noticeable increase in salinity in the streams draining that area" (Wood, 1924, p. 35). Wood (1924) proposed that land clearing increases the volume of water on the hillside that will then raise the water table near the watercourse; where this is sufficiently pervious, the water will rise through it bringing salts to the surface, and as the area dries salinity is left on the surface as a salty incrustation (see Wood, 1924, pp. 40-41, for full description).

The hillslope recharge model of Wood (1924) has been supported by subsequent work on the causes of salinity and in designing and evaluating management interventions targeted at mitigating and adapting to land degradation caused by salinity (Hatton and Salama, 1999; Hatton and Nulsen, 1999; Hatton et al., 2003). Conacher (1982) and George and Conacher (1993) identified four mechanisms for the development of salinity: (1) increased overland flow and surface runoff; (2) increased regional groundwater throughflow and the development of perched aquifers; (3) increased infiltration to deep aquifers leading to rising water tables; and (4) increased soil throughflow and infiltration to deep groundwater, leading to a mixing of perched and deeper aquifer systems in saline seeps. George and Conacher (1993) and George et al. (2008) found that event recharge is significant, and large rainfall events can account for large proportions of annual recharge and lateral expansion of the salinised area. Similar to Wood, George and Conacher (1993) proposed that the third mechanism was the dominant causal process leading to secondary salinity in dryland areas.

Managing salinity has focused on what Hatton and Nulsen (1999) termed functional ecosystem mimicry, where perennial vegetation was re-introduced into the landscape. Evaluation of this effort found that in areas of higher rainfall and on sandplain seep sites, recharge management has delivered direct impacts in reducing groundwater levels and the expansion of areas affected by secondary salinity (George et al., 1999; Bell et al., 1990; Bennett and George, 2008). Results from low-gradient areas with valley floor salinity and in lower rainfall zones $\left(<600 \mathrm{~mm} \mathrm{yr}^{-1}\right)$ display no evidence of positive impacts (George et al., 1999; Johnsen et al., 2008). This raises the question as to whether the extent of intervention (revegetation) is not sufficient (Hatton and Nulsen, 1999) or whether there is an important process re- 
sponse difference between the higher-gradient and rainfall areas that are more hydrologically connected and the drier and lower-gradient landscapes. There is the potential that adapting the understanding from one landscape type (wetter and connected) to another (drier, flatter and disconnected) has not been able to capture the full subtly of processes causing land degradation by salinity in the drier and flatter setting.

\subsubsection{Surface water redistribution and dryland salinity}

Less extensively reported in published work on causes of salinity is work that highlights the potential role of surface runoff. Teakle and Burvill (1938) reported that in addition to the processes captured by Wood's (1924) hillslope recharge model, dryland salinity can develop due to two additional factors. A seasonally perching aquifer (saturated source area) was observed to form where regional groundwater throughflow emerged at the break of slope or due to subsurface structural features (such as dykes and silicified fault plains). This results in saline waterlogging or a hillslope saline seep, developing as a seasonal feature this is common in sandy surface soils over clay and for deeper sand soils termed by George (1990) as "sandplain seeps". The second mechanism reported by Teakle and Burvill (1938) was related to observations of surface expressions of salinity were that the water table was not directly connected to the soil surface. Teakle and Burvill (1938) suggested that these developed in poorly flushed soils where salts are moved vertically through the unsaturated zone by diffusion in soil moisture and evapoconcentration at the surface. They reported that salinity developed where the saline water table was between $4 \mathrm{ft}(1.2 \mathrm{~m})$ and $10 \mathrm{ft}(3.0 \mathrm{~m})$ b.g.l. (below ground level) at the end of winter, but it was most common where the saline water table was less than $5 \mathrm{ft}(1.5 \mathrm{~m})$ b.g.l. and in cracking and swelling clays depressions "where the micro-relief favours surface evaporation" (Teakle and Burvill, 1938, p. 243).

Nulsen (1981) found that a saline groundwater depth of $1.8 \mathrm{~m}$ b.g.l. was a critical limit on wheat crop growth in the drier and flatter landscapes, well below the rooting zone of this annual species. Nulsen and Henschke (1981) reported the lateral redistribution of runoff from hillslopes to the valley floor where there was groundwater recharge through preferred-pathway flow on the valley floor. In a different setting, Jones (2000a, b) questioned the recharge efficiency of grasslands and the role of taproots as a vertical pathway for groundwater rise to cause salinity in a low hydraulic conductivity sub-soil (as proposed by the hillslope recharge model). They suggested that surface flows may be important in causing salinity in low-gradient landscapes. Bann and Field $(2006 \mathrm{a}, \mathrm{b})$ used the term "surface-water salinity" in southeastern Australia to describe similar processes of surface water redistribution and valley floor vertical recharge causing salinity. Other works describe how waterlogging caused by the buildup of water behind topographic obstacles, such as roadways or railways with poor culvert capacity as a cause of salinity (Cattlin, 2006; Cattlin and Farmer, 2004; Cattlin et al., 2002). Nathan (2000), working on salinity in the Dundas Tablelands of Victoria, also highlighted limitations of the conceptual understanding of vegetation clearing and the groundwater recharge model of salinity.

\subsubsection{A role for surface water redistribution causing salinity}

In summary, the pervasive conceptual understanding of salinity is based on the hillslope research model of Wood (1924) and subsequent work by George and Conacher (1993) and others. Causal processes can be summarised as land clearing altering hydrology in favour of higher hillslope recharge that causes rising salinity groundwater that degrades soil and water resources in low-lying landscapes. This understanding may have some limitations in adequately resolving dynamics of water and salt flux and pathways of salt accumulation within the unsaturated root zone, especially given that lateral groundwater flow rates are so low (McFarlane et al., 1989). The potential role of surface water runoff and redistribution are not well understood in dryland, saline environments and the role that these may have as a contributor to salinisation.

In this paper we investigate surface streamflow and surface-to-groundwater connectivity data from a highresolution gauging network within a dryland catchment to determine whether there is evidence to suggest a role for surface water processes as a contributor to secondary dryland salinity. The initial focus is the long-term, end-of-catchment gauging data and is evaluated with respect to the prevailing understanding of hydrological partitioning of fluxes through the hillslope recharge model, as applied to a hydrologically connected landscape. Data on water and salt yield from a high-resolution internal catchment gauging network (above the long-term gauge) that was operated for 6 years are used to investigate surface water runoff and patterns of catchment internal water redistribution and connectivity and salt flux and yield from the landscape. Data from a surface-watergroundwater (SW-GW) interaction site on a valley floor area with micro-topography and surface water inundation are then evaluated in relation to water fluxes and implications for salinity processes. Finally, data on water transmission and salt yield from a management intervention, where a broad-based channel were constructed to remove microtopography, reduce inundation and increase connectivity in a valley floor location, are evaluated in relation to the role of surface water in dryland salinity and the effectiveness of this intervention.

\section{Experimental site and data collection}

\subsection{Study site}

Toolibin Lake is an ephemeral wetland catchment $\left(485 \mathrm{~km}^{2}\right)$, within the broader Blackwood River catchment located in the 


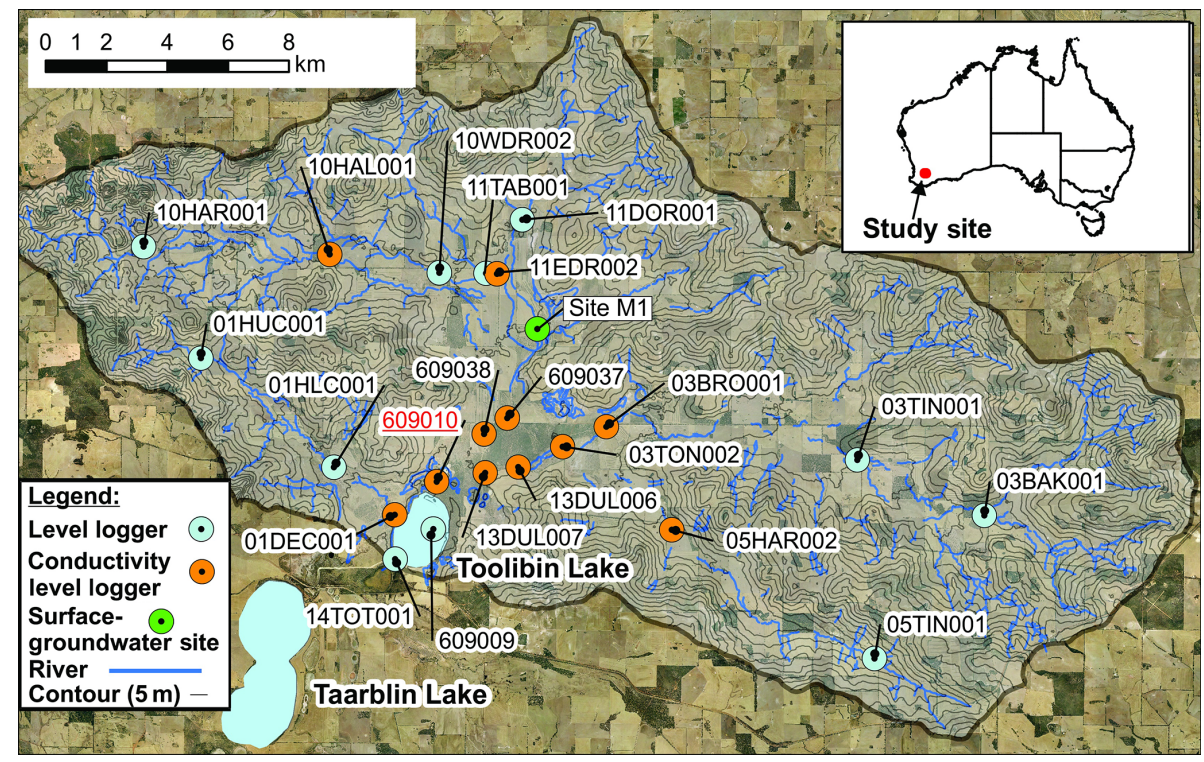

Figure 1. Toolibin Lake catchment showing the monitoring sites coded according to whether conductivity and/or level data are recorded. Drainage lines highlight the often discontinuous and meandering surface hydrologic pathways with poor downstream connectivity in the valley floor. Map created with field data and open-access data through the Western Australia Government Shared Location Information Platform and Creative Commons data from Geoscience Australia.

Wheatbelt region of Western Australia (Fig. 1). The catchment sits atop the Yilgarn Craton, a deposit of primarily granitoids of Archean craton age. Deep weathering of these granitoids and lateralisation occurred under a previous wetter and more humid climate (Mulcahy, 1967; Johnstone et al., 1973), leading to the characteristic duplex (texture contrast) lateritic soils typical of the region (Commander et al., 2001; Verboom, 2003). Due to the age and stability of the landscape, salts derived from oceanic aerosols have accumulated in the soils and groundwater of this region (Hingston and Gailitis, 1976), and relict palaeodrainage features affect contemporary movement of the (typically saline) groundwater and influence surficial hydrological processes (van de Graaff et al., 1977; Beard, 2003; Clarke, 1994; McFarlane et al., 1989). The Toolibin Lake catchment is $140 \mathrm{~km}$ east of the Darling Range atop the Yilgarn Plateau, with a gently sloping hillslope and predominantly wide and flat valley floor landforms that have significant local micro topography and overlie palaeochannel valley-fill sediments (Commander et al., 2001; Beard, 2003).

The region has a Mediterranean-type climate, experiencing cool and wet winters, with hot and dry summers. Winter rainfall results from cold fronts embedded in westerly moving low-pressure cells passing over the region (Sturman and Tapper, 1996). Floods are associated with both lows from former tropical cyclones that can track across the region during the months of November to April and cold fronts that bring widespread (though lower intensity) rainfall during winter and spring months, typically on a wet catchment. Average annual rainfall (from 1975-2009) in the Toolibin Lake catch- ment grades west to east from 390 to $350 \mathrm{~mm}$ (Callow et al., 2008). There is high annual rainfall variability and a marked decreasing trend since the mid-1970s for stations in this catchment (Callow et al., 2008), consistent with what is reported for southwestern Australia (Smith et al., 2000; Indian Ocean Climate Initiative, 2002; Callow and Smettem, 2007). Stations now receive an average of 40 to $80 \mathrm{~mm}$ per year less than the pre-1975 average in this catchment (Callow et al., 2008). Hence, rainfall data are analysed within this paper with reference to the post-1975 period, rather than the entire record (except where otherwise stated).

The landscape was originally dominated by diverse Eucalypt woodlands and heathlands. Minor clearing began in the late-nineteenth century, concentrated on clay-rich areas in valleys, with the upper Toolibin Lake catchment areas cleared mostly after World War II and continuing until the 1970s as agriculture became increasingly mechanised (Watson, 1978). Only around $10 \%$ of the native vegetation remains, and current land use is dominated by annual cereal cropping and pasture grazing by sheep, often in mixed cropping-livestock systems (Callow et al., 2008; Muirden and Coleman, 2014).

A long-term streamflow gauging station is operated by the Department of Water and Environmental Regulation (DWER) just above Toolibin Lake (Station 609010; Fig. 1). Rainfall data were obtained from long-term Australian Bureau of Meteorology rainfall stations at Wickepin (Station 10654; opened 1912) and Avoca (Station 10671; opened 1930), as they contain the longest continuous record and are located to the northwest and southeast of the catch- 
ment. A high-resolution surface water gauging network was installed and operated from 2007 to 2012 to measure internal catchment hydrological yield and patterns of connectivity, salt yield, and redistribution (Fig. 1).

A combination of capacitance probe loggers (Scott Parsons Electronics (SPE) USB capacitance loggers), In-Situ Aqua TROLL 200 integrated level (pressure) and conductivity probes, and Unidata 6536D conductivity loggers were installed to monitor streamflow, salinity and groundwater levels. Sites were serviced every 3 months, with loggers downloaded and sensor calibration of capacitance probes in "dirty" and then "clean" conditions used to create a phased linear change calibration managed in a Hydstra hydrological database. Due to the salinity of streamflow (that can exceed the salinity of seawater), laboratory testing of capacitance loggers was undertaken to determine their overall accuracy and susceptibility to calibration drift under higher salinity water (Callow et al., 2008). Accuracy was better than $\pm 10 \mathrm{~mm}$ at full scale under all conditions, with a mean error of $3 \mathrm{~mm} \mathrm{(} 2 \mathrm{~m}$ is full scale; i.e. $<0.5 \%$ error) for all calibration tests across water that varied in salinity from tap water $\left(\sim 400 \mathrm{mg} \mathrm{L}^{-1}\right)$ to water approximating seawater (33000 $\mathrm{m} \mathrm{L}^{-1}$ ) (Callow et al., 2008). Sites recording conductivity were used to calculate salinity and salt load by converting conductivity to salinity (or total dissolved salts; TDSs) (Callow et al., 2008). Salt and water flux is reported based on a water year, starting from 1 April each year.

Gauging sites were surveyed using either a Topcon total station or a Magellan ProMark3 real-time kinematic differential global positioning system (RTK-DGPS) (depending on the tree canopy density). A Valeport 801 single-axis electromagnetic velocity meter was used to gauge streamflow greater than $7 \mathrm{~cm}$ deep that occurred during gauged events in 2007, 2008 and 2012. Point survey, gauging and lidar data (where available) were also used to calculate stage-discharge rating curves using the 1-D Hydrologic Engineering Center's River Analysis System (HEC-RAS) (US Army Corps of Engineers, 2008), with stage and salinity data plus rating curves managed within the Hydstra programme used to calculate total discharge and salt loads. Details on data review and quality control are described in detail by Muirden and Coleman (2014).

A surface-water-groundwater interaction monitoring site was established at Site M1 (Fig. 1) in April 2008. RTKDGPS was used to collect over 7000 spot heights through a 0.28 ha valley floor site, with points of vertical accuracy lower than $3 \mathrm{~cm}$ excluded, to create a valley floor $0.5 \mathrm{~m}$ digital elevation model (DEM). Site M1 was located in a DEM mapped surface water inundation area. Upstream and downstream surface water loggers were also installed to monitor surface inflow and outflow, with the Department of Agriculture and Food Western Australia (DAFWA) pluviometer rain gauge ("Martins") located $2 \mathrm{~km}$ from this site. A 4.5-inch $(114 \mathrm{~mm})$ hollow-stem auger was used to drill to a depth where the pallid zone (chemically weathered kaolinitic sapriolite) was reached, with 3 -inch $(76 \mathrm{~mm})$ plastic inserts used to collect core samples. Fully slotted PVC pipe ( $80 \mathrm{~mm}$ Class 12 pressure pipe) was inserted as an observation bore. Solid-stem augers ( 3.5 inch) were then used to target drilling into three identified permeable layers to install deep (drilled to $6.2 \mathrm{~m}$; slotted from 5-5.5 m), intermediate (drilled to $4.5 \mathrm{~m}$; slotted from 3.6-4.0 m) and shallow (drilled to $2.5 \mathrm{~m}$; slotted from 1.4-2.0 m) piezometers. Piezometers were $50 \mathrm{~mm}$ Class $12 \mathrm{PVC}$ solid pressure pipes with slotted sections in target layers, sealed above and below the target layer with bentonite (pellets). Loggers were installed in groundwater monitoring infrastructure (15 min logging) and the surface water sites (5 min logging), calibrated to protocols outlined. Vertical hydraulic gradient was used to indicate up or down water flux direction, calculated for the shallow to intermediate and intermediate-to-deep piezometers, determined as the overall difference of the water levels divided by the mean depth difference of the slotted section.

\subsection{Valley floor channel construction}

During 2009, a new waterway was constructed to the connected stations 609037, 609038, 03TON002 and 05HAR002 concentrating flow directly into Dulbinning Lake (Fig. 1 for locations). The waterway was located based on lidar and high-resolution topographic surveying to identify low points and to connect them, preventing transmission loss and internal storage. The waterway was designed and constructed as a low-gradient, broad-based channel, approximately $25 \mathrm{~m}$ wide and $0.4 \mathrm{~m}$ deep and running at the valley floor gradient $\left(\sim 0.0003-0.0015 \mathrm{~m} \mathrm{~m}^{-1}\right)$ and designed to carry a $1: 3$ year flow (Fig. 2). The waterway was constructed with the spoil removed to allow lateral inflows from adjacent areas of the reserve and to ensure that spoil dump levees (as is the norm for the construction of such channels) did not exacerbate waterlogging on areas lateral to the constructed channel and hydrologically disconnect the channel from the wetland and prevent lateral inflows. The design allowed for larger flows to spread and dissipate across the valley floor but then drain back into the channel on the falling limb of the flow pulse.

\section{Results}

\subsection{Hydrological yield at catchment outlet}

The long-term gauging station collects data between Dulbinning Lake and the inflow to Toolibin Lake (DWER Station 609010; Fig. 1). Analysis of the long-term gauging record for Toolibin Lake inflows (Station 609010) from September 1978 to December 2012 reveals that flow is only recorded on $4 \%$ (502 of 12563) of days, with flow only during $13 \%$ (53 of 417) of months and $40 \%$ (13 of 34) of years recording no flow days across the entire water year. The $1: 5$ year and $1: 10$ average recurrence interval (ARI) peak streamflow is 2 and $10 \mathrm{~m}^{3} \mathrm{~s}^{-1}$, respectively, from a catch- 


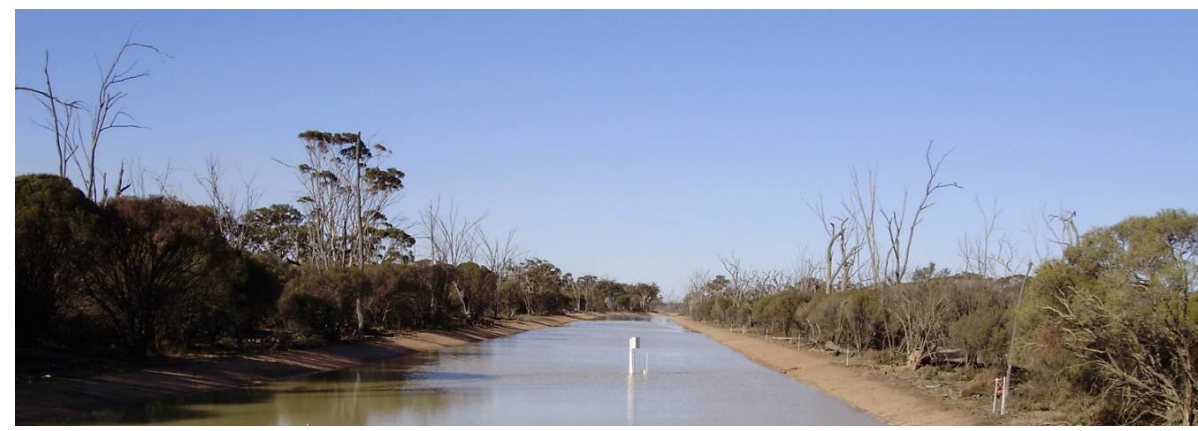

Figure 2. New broad-based channel implemented in the Dulbinning Nature Reserve. Channel dimensions at this location are $23 \mathrm{~m}$ wide and $0.55 \mathrm{~m}$ deep. Water depth in this image is $0.18 \mathrm{~m}$.

ment with an area of $485 \mathrm{~km}^{2}$ with an average rainfall of around $360 \mathrm{~mm}$. In such low-gradient environments, there is some uncertainty in rating and gauging, and a recent revision of the rating curve by DWER has revised cease-toflow thresholds and low flow. If retrospectively applied to this data, it suggests flow occurred on $1496(11.9 \%)$ days and during $126(30.5 \%)$ months and at some time during 29 of 34 years, though the average difference of annual total flow between the rating used in this paper and the revised rating imposed on data was $3.34 \mathrm{ML}$ per year $(0.3 \%$ difference) across the study period 2007-2012. Irrespective of any uncertainty, the gauging data characterise this catchment as one with an ephemeral flow regime with long periods of no or only very low flows.

The infrequent inflow events to Toolibin Lake tend to occur at two times; either the end of winter and early spring in wetter years or in summer due to activity from former tropical cyclones. Winter streamflow is only typically experienced during June to September, with mean monthly discharges of 140, 394, 184, $105 \mathrm{ML}$, respectively. January has an anomalously high mean monthly discharge relative to non-winter or spring months (142 ML), skewed by one event, the highest on record which occurred during the summer 1982 floods associated with the former Tropical Cyclone Bruno. For average streamflow by rainfall decile, summer events show a significant threshold jump for streamflow between decile 7 (30 ML) and decile 8 (366 ML) years, but for late winter and early spring events, this occurs between decile 5 (153 ML) and 6 (915 ML). Mean average annual discharge at the long-term gauge is $170.6 \mathrm{ML} \mathrm{yr}^{-1}$ (Muirden and Coleman, 2014), which equates to a mean annual runoff yield of streamflow of $0.14 \%$ of rainfall.

\subsection{Internal runoff generation, water redistribution and hydrological connectivity}

\subsubsection{Water yield}

The high-resolution gauging network is depicted schematically in Fig. 3 and presents results for annual flow of wa- ter (black) and salt (red, for sites with those data) within the Toolibin Lake catchment. The streamflow data highlight that flows frequently occur upstream of the long-term gauge, and annual yield and flow are higher at some of these locations than at the downstream location. During the dry years of 2007 (i.e. water year starting 1 April 2007 including the winter (wet season) of 2007) and 2010 and the low-flow year of 2011 (at the end-of-catchment gauge; Station 609010), there are significant flows and water redistribution with the catchment that do not connect through to the long-term gauging site.

Based on post-1975 rainfall data, the study period included an average year (2007 - decile 4), two wetter years (2008 - decile 8 and 2011 - decile 9) and three extremely dry years (2009 - decile 1 and 2010 and 2012 which respectively represented the driest and second driest years since 1975). Flow yield at the long-term gauge recorded zero flow in the decile 4 year (2007), and flow in the decile 8 (2008) rainfall year is consistent with the activation thresholds discussed above for this site based on the analysis of the full streamflow record (since 1978). Data from the high-resolution gauging network show that in 2007 there was significant streamflow within the catchment, but this did not connect to the longterm gauging station. Internal catchment surface water redistribution also occurred in the other no-outflow year (2010, which was the second driest year on record), with up to $66 \mathrm{ML}$ of discharge measured at internal catchment gauges.

Due to the management intervention to increase hydrological connectivity, results for streamflow after 2009 in locations downstream of the Dulbinning Nature Reserve (including the long-term gauge) need to be considered in the context of the surface water engineering interventions that have changed catchment behaviour (see Sect. 4.4). Streamflow at the long-term gauge was recorded during the wet years of 2008 (decile 8) and 2011 (decile 9) but also the dry years of 2009 (decile 1, with large rainfall event) and 2012 (decile 1 and the flow that is the second driest on record from a late-summer event) that post-dated this management intervention. 

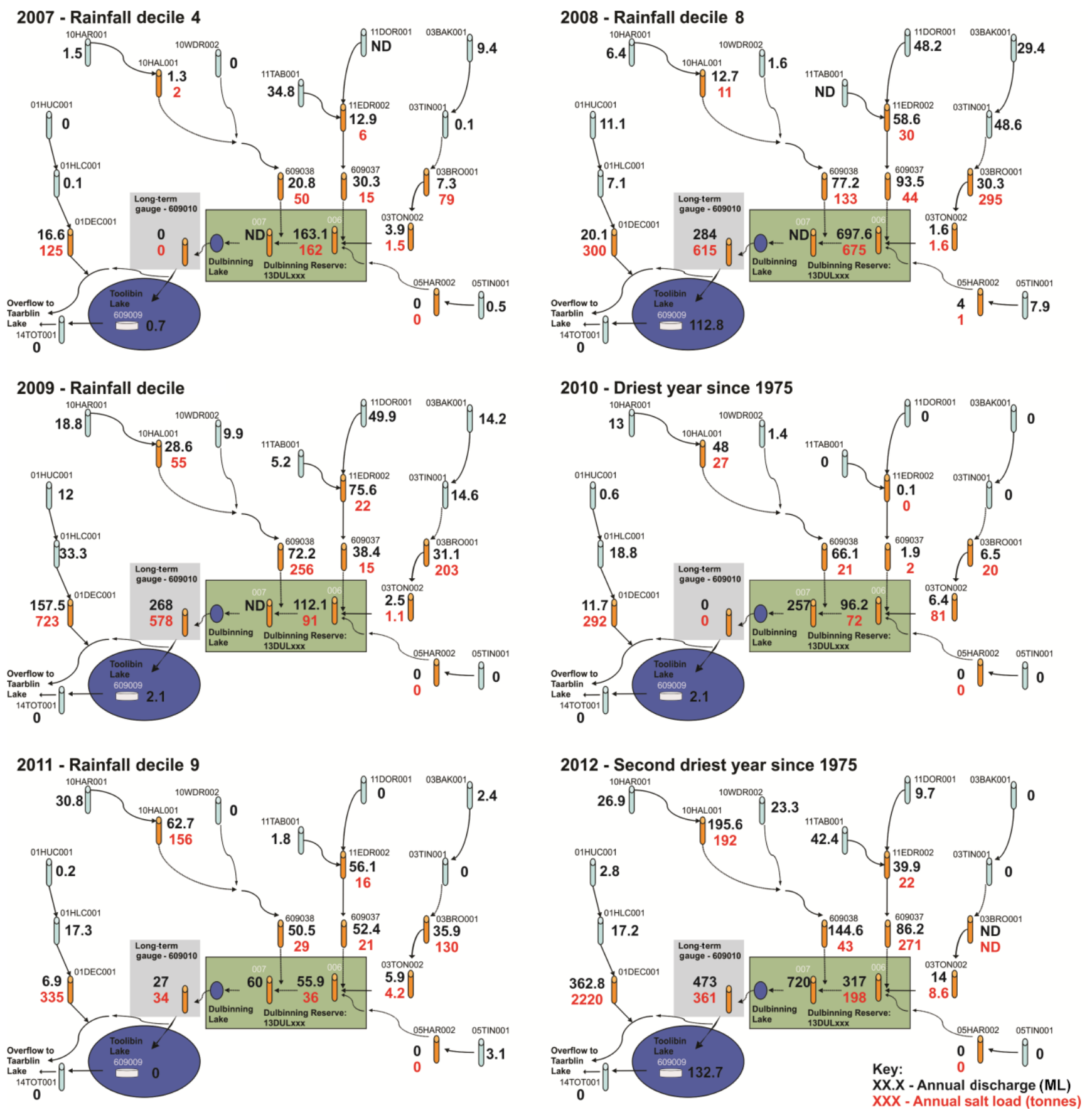

Figure 3. Annual discharge data (ML) (black data) and salt load (tonnes per year in red) for the different gauging stations across the study period (2007-2010). Note that ND is no data due to equipment failure.

\subsubsection{Salt yield}

Opportunistic sampling of water quality during a flow event in July 2007 found that the gauging sites in the east of the catchment had salinity values comparable to rainwater on hillslopes, measured at $\sim 100 \mathrm{mg} \mathrm{L}^{-1}$ during rainfall events with short-lived runoff. Logger data for the same event reported values of $2150 \mathrm{mg} \mathrm{L}^{-1}$ at 13DUL006 within the Dul- binning Nature Reserve, and Stations 609037 and 609038 have salt concentrations peaking at 4000 to $13600 \mathrm{mg} \mathrm{L}^{-1}$.

Salt loads calculated at the 10 stations measuring conductivity and flow through the network present a complex pattern of salt flux and export. In 2007, there was significant net input of salt from the surrounding landscape to the valley floor (i.e. Dulbinning Nature Reserve), which is not transferred through to Toolibin Lake (no flow recorded the long-term 


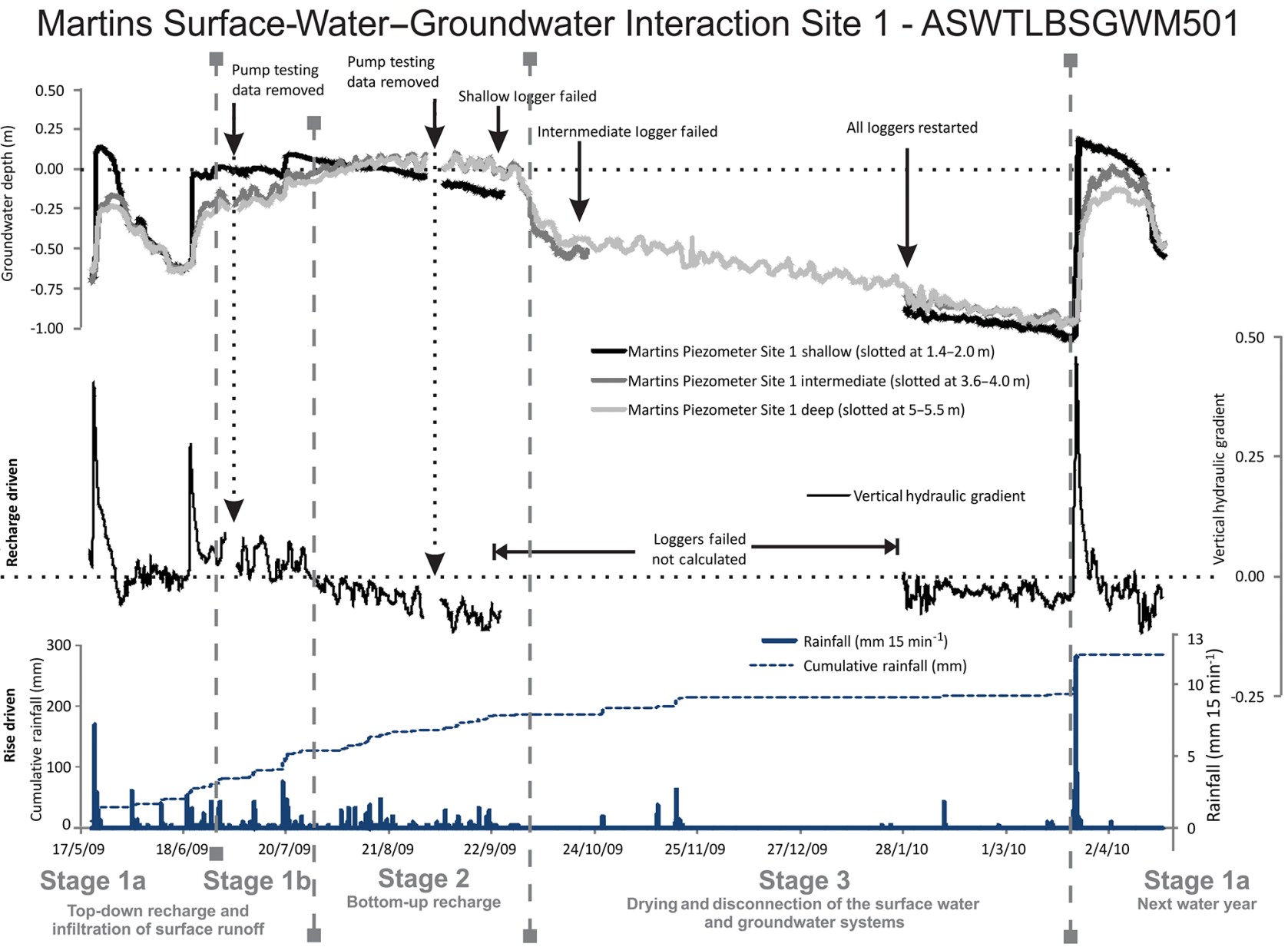

Figure 4. Groundwater data for Martins Site M1, showing the movement of the shallow, intermediate and deep piezometers and the overall vertical hydraulic gradient from May 2009 to June 2010 and three stages of SW-GW interaction.

gauge at Station 609010). A salt load of $66.5 \mathrm{t}$ was measured entering the reserve (Station 609037: $15 \mathrm{t}$; Station 609038: $50 \mathrm{t}$ and 03TON: $1.5 \mathrm{t}$ ) which increased to $162 \mathrm{t}$ at 13DUL006 in the middle of the Dulbinning Nature Reserve. There was no streamflow at the entry to Toolibin Lake (609010), so no export of the salt from the Dulbinning Nature Reserve and Dulbinning Lake in that year. In 2008 (a wet decile 8 rainfall year), there were numerous streamflow events connecting through the landscape during winter. Data suggest that during this wetter year, there was an initial flushing of surface stores of salt followed by a sequence of flow events that allowed for limited input of salts from the surrounding landscape onto the valley floor. In some years (2009 and 2012), there appears to be a larger export of salts through the longterm gauge into Toolibin Lake (Station 609010) than entering the Dulbinning Nature Reserve in that single year.

\subsection{Surface-water-groundwater connectivity and vertical recharge processes}

A surface-water-groundwater interaction site was established to measure the direction of vertical water movement in a valley floor landscape. Data from the SW-GW interaction site across a water year identify three broad characteristic stages (Fig. 4). At the end of summer, the valley floor areas are dry and characterised by large surface cracks, up to $3 \mathrm{~cm}$ wide and $50 \mathrm{~cm}$ long and greater than $30 \mathrm{~cm}$ deep. The first stage (Stage 1) is dominated by surface flows that drive top-down recharge but has two sub-stages $(1 \mathrm{a}, 1 \mathrm{~b})$ within it. Initially, infiltration relative to rainfall is rapid and responsive (Stage 1a; Fig. 4), where macropores likely facilitate rapid infiltration of direct rainfall and surface flows (runon) that has a rapid preferential pathway flow and allows rapid top-down early-season recharge. As the water year progresses, the system transitions to a state still dominated by surface inundation and top-down recharge, but where the hydrological response and recharge rates relative to rainfall 
is more subtle (Stage 1b). As soils saturate and macropores close, matrix flow becomes the dominant flux mechanism, and the seasonal surficial aquifer becomes connected. The system behaves as a semi-confined aquifer similar to Drake et al. (2013), though the vertical hydraulic gradient still remains downwards through to mid to late winter.

As the aquifer connects, there is evidence for a transition to the bottom-up groundwater discharge in later winter and early spring months (Stage 2). At this stage the hydrological behaviour is as expected under the hillslope recharge model, whereby hillslope recharge and lateral movement of groundwater to the valley floors drives a negative hydraulic gradient pushing shallow groundwater vertically, a bottom-up groundwater response. Groundwater potentials reach or exceed the ground surface, and fresher surface water flows created the potential for the vertical diffusion of salts via matrix flow due to the concentration gradient from saline soil to fresher inundation. Where surface inundation ponds salts are subject to evapo-concentration and ultimately retained in the surface soils or as a surface salt crust or when inflows exceeded depression storage thresholds, salt may be exported horizontally and down system.

From late spring, the system dries and groundwater levels fall and then de-couples from the surface (Stage 3). Soils desiccate and macropores re-develop as the system is reset for the subsequent water year, or in the case of March 2010, a dry-season thunderstorm (Fig. 4), with a similar top-down and highly responsive behaviour to rainfall (Stage 1a). While the shallow and intermediate loggers failed during much of the drying-out "Stage 3" and hydraulic gradients cannot be calculated during this time, the deep logger records a transition in groundwater response to rainfall. There is almost no response in groundwater to the limited number of small rainfall events during the dry season (from October to March or April over the summer dry season), and there is a downward groundwater trend across October until the following April. The April 2010 thunderstorm event caused significant recharge and initiates a return to Stage 1. While two of three loggers had failed during Stage 3, the deep logger supports the interpretation that the surface and groundwater systems disconnect over the dry season.

\subsection{Manipulating surface water connectivity}

The new channel constructed in the Dulbinning Nature Reserve aimed to increase connectivity of otherwise ponded areas in the valley floor to enhance the overall water yield and reduce salt export to Toolibin Lake. The hypothesis was that by minimising ponding, the time for exchange and accumulation of salts from groundwater into the surface water would be reduced and thereby reduce the load exported downstream. Following construction in early 2009, the hydrological behaviour of the catchment, as represented by the end-of-catchment gauge (Station 609010), can be seen to change markedly (Fig. 5). This demonstrates a considerably

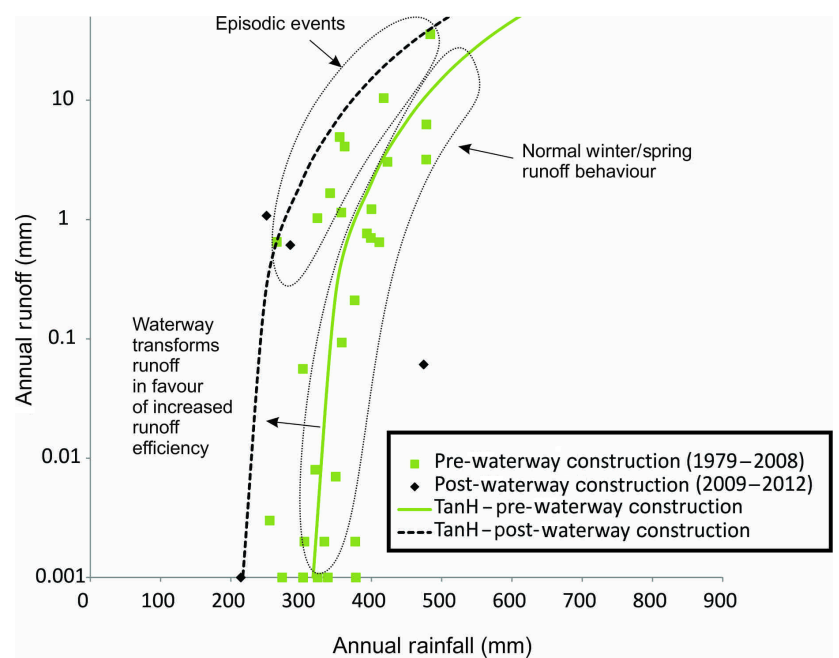

Figure 5. The annual rainfall-runoff data show the role that microtopography plays within low-gradient drylands, with a pronounced change in runoff efficiency recorded at the long-term gauge after the construction of the waterway through the Dulbinning Nature Reserve in 2009.

higher yield as water is more efficiently transmitted from landscape positions receiving runon from further upstream areas (similar to location M1, presented in Sect. 3.3) and less impacted by micro-topography in the valley floor. This occurred in all post-construction years (2009, 2010 and 2012), aside from 2011. This anomalous result is most likely a response to the re-wetting of the catchment and high total, but low-intensity, rainfall that was experienced after the driest year on record (2010); the combination of numerous lowintensity events and dry antecedent conditions considerably reduced the runoff efficiency. This confirms the challenge of ascertaining hydrological behaviour from the gauge lower in the landscape and the high non-linearity occurring in these landscapes with weak gradients and highly episodic rainfall. Analysis of salt load transmitted in the limited number of events post-construction found that the salinity of streamflow reaching Toolibin Lake was $20 \%$ lower when compared to similar magnitude events before construction.

\section{Discussion}

The results from the long-term, end-of-catchment gauge are consistent with the interpretation of functional catchment hydrology and the pervasive model of dryland salinity, that is, low runoff and inferred high hillslope recharge that drives groundwater rise. However, the data from a high-resolution internal surface gauging network, combined with the results from a valley floor SW-GW interaction site and the management intervention to improve hydrological connectivity, all suggest an important role for surface water processes in the redistribution of salt and the ultimate manifestation of dry- 
land salinity within low-gradient dryland landscapes. In particular, variability and threshold behaviour in surface water processes that lead to water runon and valley floor inundation are important in shaping dryland salinity in low-gradient valley floor locations where microtopography creates the potential for surface ponding and vertical salt movement via diffusion. The insights from this dataset allow us to refine and add to the conceptual model for the hydrologic drivers of dryland salinity.

\subsection{A water balance approach to the hillslope recharge model}

Applying a water balance approach from the long-term gauge to quantify fluxes as the basis for the hillslope recharge model of salinity yields an average annual runoff of $0.14 \%$ of rainfall. The remaining $99.86 \%$ must be accounted for by losses as infiltration to groundwater (and/or change in storage) transpired by trees or evaporated from the surface. Whilst evapotranspiration potential is high in this landscape (average annual potential pan ET of $1897 \mathrm{~mm}$ for 20082018 at Wickepin; DPIRD, unpublished data), Beringer et al. (2016) reported mean annual actual evapotranspiration (AET) at $261.7 \mathrm{~mm} \mathrm{yr}^{-1}$ (or $72 \%$ of rainfall) for the native ecosystem Great Western Woodland OzFlux site that has an annual rainfall $\left(361.1 \mathrm{~mm} \mathrm{yr}^{-1}\right.$ ) comparable to the Toolibin catchment. Unpublished data from the cropping and farmland Ridgefield OzFlux site suggest a similar proportion of AET at $330 \mathrm{~mm} \mathrm{yr}^{-1}$ with an average annual rainfall of $445 \mathrm{~mm} \mathrm{yr}^{-1}$ (average evapotranspiration was $74 \%$ of rainfall; Beringer, unpublished data). Accepting AET as $72 \%-74 \%$ of rainfall, recharge to groundwater and change in storage would be around $26 \%-28 \%$ of precipitation or around $90 \mathrm{~mm} \mathrm{yr}^{-1}$. This figure is significantly higher than the upper value suggested by George (1992) and George and Conacher (1993), who propose values in the range of 5.5$27 \mathrm{~mm} \mathrm{yr}^{-1}$ for cleared agricultural land (equating to $1.5 \%-$ $7.5 \%$ of rainfall at this site). If recharge was $26 \%-28 \%$ of precipitation, groundwater levels in valley floor locations would be rising at least $1-2 \mathrm{~m}$ per year (assuming specific yield or effective porosity values are 0.1 to 0.05 respectively). Local or regional groundwater data certainly do not support such a high value (Bennett and George, 2008; Mouat et al., 2008).

This paper presents evidence of significantly higher rates of internal runoff than that recorded at the long-term gauge. While measured surface flow fluxes at sites from the internal gauging network only approached $5 \%$ runoff coefficients, there remains significant uncertainty in the calculation of these figures. These are based on catchment area as defined by an upslope area of a pit-filled (coarse-resolution; $10 \mathrm{~m})$ DEM. This is likely to significantly overestimate actual contributing catchment area, particularly in agricultural landscapes with banks and farm hillslopes dams harvesting surface water and low-gradient valley floors where the catchment area will be dynamic with depression storage and activation (Ryan et al., 2015; Callow and Smettem, 2009; Callow et al., 2007). Significant surface flows not recorded in this gauging network are captured and stored on hillslopes in farm dams (Ryan et al., 2015; Callow and Smettem, 2009). Flows reaching the valley floors are likely contributing to top-down recharge (i.e. Site M1, Stage 1), followed by likely evaporation from surface inundation on valley floors. Within this catchment there is a high pan potential ET through the months when surface inundation occurs (i.e. Site M1, Stage 2), with PET recorded at Wickepin in June to September respectively being 57, 53, 72 and $113 \mathrm{~mm}$ per month (DPIRD, unpublished data). This flux is not accounted for AET measured by flux tower sites mentioned above that are located in vegetated stands with no surface water inundation.

\section{2 (Re-)Conceptualising surface water flows and dryland salinity}

The results from the high-resolution gauging network and other observations show a similar pattern of hydrological behaviour similar to work by Farmer et al. (2001, 2002), Cattlin et al. (2004), and Cattlin (2006). They applied the terms "shedding" and "receiving" to these landscapes, suggesting that upper shedding landscapes yielded significant volumes of fresh runoff that failed to connect and flow through the system, as it ponded in the flatter receiving landscapes. A similar though subtly different pattern is found in this study. There is an upper landscape that yields fresh runoff (termed a "flow" landscape) that contributes runoff (or runon) to valley floor areas with high detention storage and microtopography but becomes seasonally activate as storage is exceeded, behaving similar to that described at Site M1 (Fig. 4; "fill" landscape). Further downstream, there are larger internal storages and lakes (Dulbinning Lake and Toolibin Lake) that only yield flow in the wettest years or in the largest event flows ("flood" landscapes). We therefore propose this "flow-fillflood" conceptualisation of the landscape water and salt flux (Fig. 6).

To further test this conceptualisation, we use the least squares regression TanH method of Grayson et al. (1996) to fit rainfall-runoff curves for each of the landscape components (Fig. 7). These results support the interpretation of the hillslopes and upper landscape as a flow landscape, with higher runoff yield. Flood landscapes have the next highest runoff yield (but is biased towards infrequent larger events, so it has a higher yield but lower frequency). The midcatchment, intermediate fill landscapes have very high transmission losses and a relatively low runoff yield (though more frequently flow than the downstream flood landscapes).

The role of surface water redistribution that does not connect through a landscape (runon) is a feature of drier, flatter and semi-arid landscapes (Ludwig et al., 1997, 2005; Ludwig and Tongway, 2000). Runon to a dry and desiccated surface 


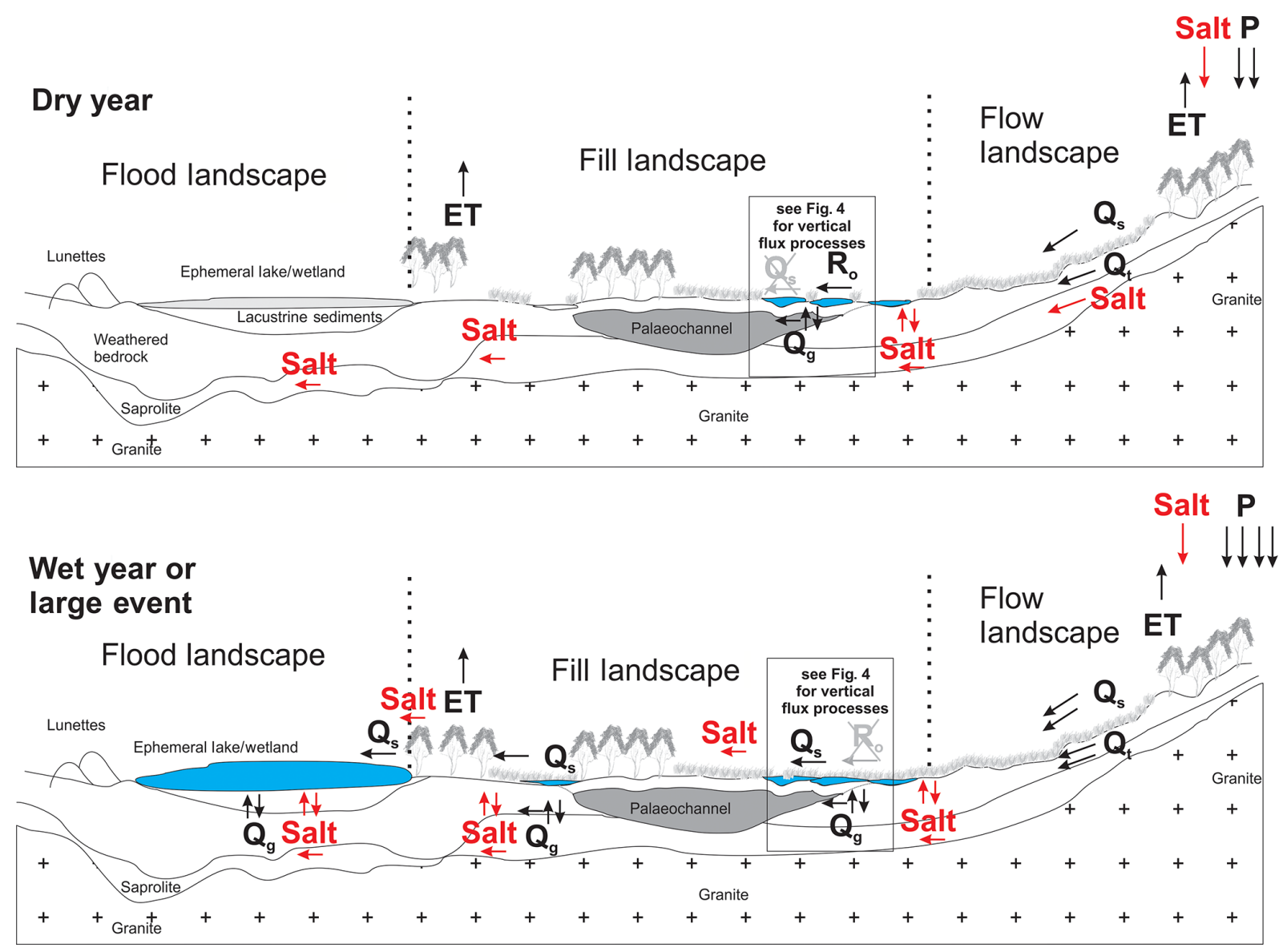

Figure 6. Flow-fill-flood conceptual model of surface water and salt flux in dryland catchments, showing disconnected flow during dry years and flow connection in wet years and large events that record flow at the end-of-catchment gauge. Hydrochemical fluxes are (water flux in black, salt flux in red): precipitation $(P)$, evapotranspiration $(\mathrm{ET})$, surface discharge or flow $\left(Q_{\mathrm{S}}\right)$, throughflow $\left(Q_{\mathrm{t}}\right)$, groundwater discharge or flow $\left(Q_{\mathrm{g}}\right)$, and runon storage $\left(R_{0}\right)$. Salt fluxes are shown in red and show how salt is moved, concentrated and then moved down system.

valley floor fill landscape was associated with a top-down recharge of surface water (Stage 1a, Fig. 4) process noted by Teakle and Burvill in the 1930s. They linked macropores and salinity, reporting that surface salt was associated with "the rims of crab-holes (expression for cracking/swelling clay depressions) where the micro-relief favours surface evaporation" (Teakle and Burvill, 1938, p. 243). While different to the pervasive hillslope recharge model, the role of surface water as a cause of salinity is consistent with processes discussed by Teakle and Burvill (1938), Nulsen (1981), Nulsen and Henschke (1981), and Cattlin et al. (2004).

Top-down recharge of surface water redistributed to the valley floor is consistent with lateral redistribution of runoff from lower slopes onto the valley floors caused groundwater recharge through the preferred pathway described by Nulsen and Henschke (1981). Drake et al. (2013) found that macropores facilitate rapid infiltration during surface water ponding in valley floors areas in the Toolibin catchment from field inundation field trials. Barrett-Lennard (2009) and BarrettLennard and Callow (2009) used a 1-D model to evaluate likely flow mechanisms at Site M1, and they could only replicate measured recharge by parameterising macropore flow during Stage 1a and then matrix flow with preferential pathways sealed for Stage 1b (see Fig. 4). Mouat et al. (2008) a noted downward hydraulic gradient in some groundwater bores in valley floor locations closer to hillslopes in this catchment. This phenomenon is consistent with our reconceptualised model of hillslope surface water redistribution to the valley floor and early-season top-down macropore (Stage 1a) and matrix flow (Stage 1b) recharge.

While the sites and data presented in this study highlight the underappreciated role of surface flows, there is still strong evidence for the role of processes as described by the hillslope recharge model of bottom-up groundwater flux as a cause of salinity in this landscape. At Site M1, Stage 2 (see Fig. 4) is dominated by bottom-up fluxes in late winter and spring, consistent with mechanisms of the hillslope recharge model of salinity proposed first by Wood (1924) and the work of George and Conacher (1993). This suggests that as this landscape becomes wetter through the water year, behaviour 


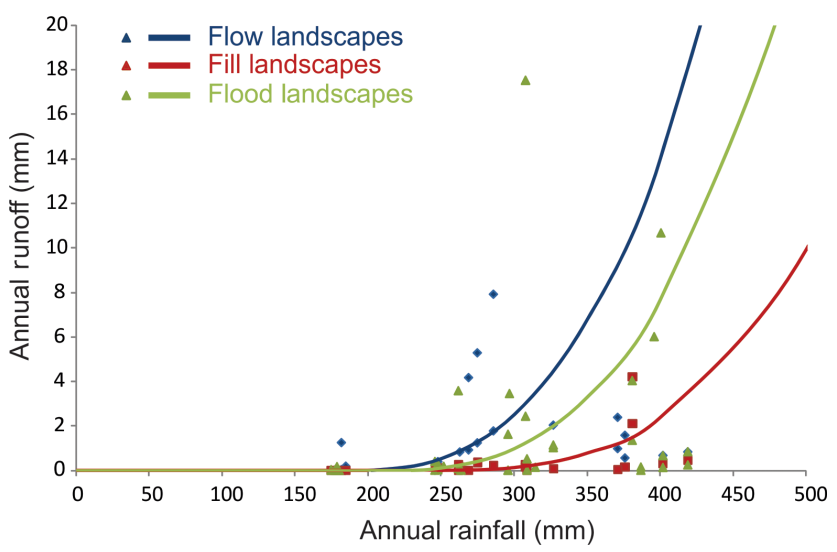

Figure 7. Rainfall-runoff TanH plot (after Grayson et al., 1996) partitioned by landscape position, identifying different hydrological behaviour in each. This indicates higher runoff from flow landscapes and the lowest runoff from the fill areas due to high transmission losses through in situ vertical recharge, with an intermediate response from flood landscapes that is influenced by these only becoming active during the greatest flows.

transitions towards the more pervasive model of hydrological behaviour and the development of salinity. Under these conditions, hillslope recharge drives a response in these lower aquifers that drive bottom-up groundwater rise in later winter to early spring (Fig. 4, Stage 2) and is likely an important contributor to salinity in low-gradient, dryland catchments. The complexity heterogeneity of the subsurface and low lateral potential due to both (low) gradient and (fine) texture (McFarlane et al., 1989) make it challenging to qualitatively resolve the processes of lateral groundwater flow and connectivity in this landscape.

Data presented on salt yield show a complex response related to the role of surface water flows and conceptualised using the flow-fill-flood model of landscape functional behaviour. In half of the years, net input into the Dulbinning Nature Reserve (fill landscape) was higher than the salt flux recorded at the long-term gauging location (flow landscape). In other years, less salt load flows into the reserve than is measured at the long-term gauge. Evidence from Site M1 (Fig. 4) shows that surface inflows and inundation may facilitate vertical groundwater movement and salt diffusion to the surface in inundated areas. In lower-rainfall and lower-flow years when fill landscapes do not contribute sufficient flow to the generation of streamflow from flood landscapes, mobilised salts stored during inundation do not connect through the landscape. They are concentrated as surface salt scalds after evaporation and desiccation and are then available for downstream flux in subsequent years. Muirden and Coleman (2014) also reported a complex pattern of annual and event flow and salinity data, noting that summer events yielded significantly lower salinity in comparison to similar magnitude winter events. Muirden and Coleman (2014) de- clared that the mechanisms behind this were unclear without further research and monitoring.

\subsection{Managing surface water drivers of dryland salinity}

The implications of the flow-fill-flood conceptualisation of surface water, landscape component flow yield and development of valley floor salinity have significant practical implications for the how hydrology and salinity might be managed. A constructed waterway was designed and built in 2009 to remove microtopography in Dulbinning Nature Reserve (fill landscape) to improve flow conveyance in stopping groundwater recharge by runon and the exchange of salts from the subsurface into the surface water. It was hypothesised that this should reduce salt yield while increasing the total flow available at the diversion structure above Toolibin Lake, allowing managers to more optimally manage the hydroperiod of Toolibin Lake (Hipsey et al., 2011; Coletti et al., 2013). Before construction, flows in a wetter year (2008; decile 8 rainfall) had a $60 \%$ transmission loss (Fig. 3) through the Dulbinning Nature Reserve. This is consistent with the results of Cattlin et al. (2004), who reported $60 \%-100 \%$ transmission losses during events between 2000 and 2003 and Callow et al. (2010) who reported an average of $50 \%$ of runoff volume lost in the reserve across the gauge record and prior to waterway construction. After construction, Muirden and Coleman (2014) reported a $25 \%$ increase in flow volume yielded through this part of the landscape. The analysis of salt load transmitted following construction found that the streamflow salinity reaching Toolibin Lake was $20 \%$ lower when compared to similar magnitude events before construction. The combination of increased flow yield and lower-flow salinity results a in significant reduction of total salt contributed downstream.

Much effort in addressing salinity has been aimed at increasing perennial vegetation in the landscape (Hatton and Nulsen, 1999). Tree planting has been found to provide benefits in areas of higher rainfall and on sandplain seep sites, where recharge management has delivered direct impacts in reducing groundwater levels and expanding saline areas (George et al., 1999; Bell et al., 1990; Bennett and George, 2008). For low-gradient and lower-rainfall zones (< $600 \mathrm{~mm} \mathrm{yr}^{-1}$ ), there has been little-to-no evidence of revegetation impacts on groundwater at the scale it has been implemented at (George et al., 1999; Johnsen et al., 2008), but it remains a popular approach in attempts to combat salinity and provide biodiversity and ecosystem service benefits (Cramer and Hobbs, 2002; Halse et al., 2003; Pannell, 2008). Ryan et al. (2015) provide an interesting paradigm to consider in the contact of this work on how hillslope vegetation and surface water management can be integrated. In the valley floor, the broad-based channel is a high-cost intervention but offers a potential to address some processes causing salinity and in some parts of the landscape. Assessing long-term vegetation 
recovery surrounding the channel was beyond the scope of this paper, but it is worthy of future research.

The constructed waterway intervention is very different to the deep-drainage approach used to combat rising groundwater salinity in valley floor locations in the Wheatbelt region of Western Australia (Ali et al., 2004; Barrett-Lennard et al., 2005; Pannell, 2001; Pannell and Ewing, 2004; Coles et al., 1999). These are based on digging a ditch or drain to a depth of around $2 \mathrm{~m}$ to intercept groundwater and dispose of the saline groundwater effluent downstream (Ali et al., 2004). Deep drainage offers limited or no economic return on investment for broadacre farming (Ali et al., 2004; Pannell, 2001; Pannell and Ewing, 2004) and has detrimental downstream environment impacts, with discharge often being acidic ( $\mathrm{pH}$ 1.9-3.8) and high in salinity (measured as up to $147000 \mathrm{mg} \mathrm{L}^{-1}$ or 4.5 times seawater salinity) (Stewart et al., 2009). Deep drains can exacerbate waterlogging and salinity through the processes identified by this study, as spoil or the removed material is dumped at the sides of the drain and causes ponding of surface water. A major cost, but important feature, in this targeted intervention was the removal of excavated soil material (used to fill low-lying areas on adjacent land). The constructed waterway was designed to convey only low-to-moderate flow events $(\sim 1: 3$ year), where lateral outflow could then return back into the channel as the flood dissipates. The performance of the broad-based channel provides further validation of the role that surface water redistribution plays in the development of salinity in low-gradient drylands.

\section{Conclusion}

This paper presents a range of evidence that surface water flows play an important role in causing salinity in lowgradient drylands, conceptualising this as flow-fill-flood functional behaviour. Much of the generation and internal redistribution of surface flows are not recorded at the long-term gauging location in this catchment. This masks the important role that (disconnected) surface flows have in this and other low-gradient dryland catchments, including as a contributor to land degradation by dryland salinity. It is shown that surface flows fill landscape detention storages, and there is topdown recharge in these locations. Inundation creates a potential for vertical diffusion of salts that can evapo-concentrate at the surface and degrade these areas or impact downstream systems when depression storage is exceeded. The broadbased channel management intervention to address surface water processes and flow-fill-flood functional behaviour has been shown to increase the yield of water and to decrease the salinity of streamflow and downstream salt yield.

Catchments in the low-gradient drylands have elements of hydrological behaviour in common with high rainfall, steeper-sloped hydrologically connected catchments of the temperate, tropical and sub-tropical areas, but they are equally influenced by processes common with dry, flat and disconnected smooth plainlands, rangelands, semi-arid regions, and deserts. Beyond this study region, the new insight from the flow-fill-flood understanding of dryland salinity further demonstrates the importance of testing and reassessing how rainfall and topography interact across a range of settings in time and space to moderate hydrological processes. It is critical to appreciate and question how catchment dynamics in the context of wet-dry, steep-flat, connecteddisconnected and related surface and groundwater processes subtly driving hydrology and, in this case, land degradation by dryland salinity. Successful management interventions need to address the specific causes of dryland salinity, but you cannot manage what you do not understand.

Data availability. This paper uses publicly available data, which are available from the relevant data custodian: the Department of Water and Environmental Regulation, the Department of Primary Industries and Regional Development (previously the Department of Agriculture and Food Western Australia; DAFWA), the Department of Biodiversity Conservation and Attractions, and OzFlux of the Terrestrial Ecosystem Research Network.

Author contributions. JNC designed the field experiment and collected data with other acknowledged assistance, and RIJV supported field interventions. JNC led data analyses, and MRH and RIJV contributed to methodological development. JNC led the writing of the paper with significant contributions from MRH and RIJV.

Competing interests. The authors declare that they have no conflict of interest.

Acknowledgements. Brian Finlayson and an anonymous referee are thanked and acknowledged for reviewing the paper and constructive suggestions. Ideas presented stem from research, observations and work initiated and refined by a number of individuals and over many decades. David Stanton, Travis Cattlin, Darren Farmer, Neil Coles and Keith Smettem are acknowledged for their significant contribution to the ideas leading to the experimental design and approach adopted. Support from the Natural Diversity Recover Catchment Program through the Department of Environmental and Conservation to the State Centre of Excellence in Ecohydrology (University of Western Australia) supported data collection, and specifically the work of Tim Pope and Ben Cohen is highlighted, and Peter Muirden is acknowledged for his work in improving the quality of these raw data. The new waterway was constructed by DPaW under the Natural Diversity Recovery Catchment Program. Alison Barrett-Lennard completed a B. Eng Hons thesis, and data reworked from that study form the basis for Fig. 4. Landholders in the Toolibin Lake catchment are thanked for permission to establish and access field sites on their properties. We acknowledge the traditional owners of the land on which this research occurred and pay our respects to their elders, past and present. 
Review statement. This paper was edited by Patricia Saco and reviewed by Brian Finlayson and one anonymous referee.

\section{References}

Abrisqueta, J. M., Plana, V., Mounzer, O. H., Mendez, J., and RuizSanchez, M. C.: Effects of soil tillage on runoff generation in a Mediterranean apricot orchard, Agr. Water Manage., 93, 11-18, https://doi.org/10.1016/j.agwat.2007.06.002, 2007.

Ali, R., Hatton, T., George, R., Byrne, J., and Hodgson, G.: Evaluation of the impacts of deep open drains on groundwater levels in the wheatbelt of Western Australia, Aust. J. Agricult. Res., 55, 1159-1171, https://doi.org/10.1071/ar04068, 2004.

Bann, G. R. and Field, J. B.: Dryland salinity in south east Australia: A localised surface water and soil degradation process?, Regolith 2006 - Consolidation and Dispersion of Ideas, CRC LEME, Hahndorf, South Australia, 9-13, 2006a.

Bann, G. R. and Field, J. B.: Dryland salinity in south east Australia: Which scenario makes more sense?, AESC2006, Melbourne, Australia, 2006b.

Barrett-Lennard, A.: Surface water ponding on low lying valley floors in south-western Australia: interactions with groundwater and its role in secondary dryland salinity, BEng Hons, School of Environmental Systems Engineering, The University of Western Australia, Perth, Western Australia, 2009.

Barrett-Lennard, A. and Callow, J. N.: Surface water ponding, insitu vertical recharge and salinity in low-gradient valleys: Toolibin Lake, southwestern Australia, in: OzWater Conference, Melbourne, Australia, 2009.

Barrett-Lennard, E. G., George, R. J., Hamilton, G., Norman, H. C., and Masters, D. G.: Multi-disciplinary approaches suggest profitable and sustainable farming systems for valley floors at risk of salinity, Aust. J. Exp. Agricult., 45, 1415-1424, https://doi.org/10.1071/ea04157, 2005.

Barron, O., Silberstein, R., Ali, R., Donohue, R., McFarlane, D. J., Davies, P., Hodgson, G., Smart, N., and Donn, M.: Climate change effects on water-dependent ecosystems in south-western Australia, J. Hydrol., 434-435, 95-109, https://doi.org/10.1016/j.jhydrol.2012.02.028, 2012.

Bartley, R., Roth, C. H., Ludwig, J., McJannet, D., Liedloff, A., Corfield, J., Hawdon, A., and Abbott, B.: Runoff and erosion from Australia's tropical semi-arid rangelands: influence of ground cover for differing space and time scales, Hydrol. Process., 20, 3317-3333, https://doi.org/10.1002/hyp.6334, 2006.

Bauer, P., Gumbricht, T., and Kinzelbach, W.: A regional coupled surface water/groundwater model of the Okavango Delta, Botswana, Water Resour. Res., 42, W04403, https://doi.org/10.1029/2005wr004234, 2006.

Beard, J. S.: Palaeodrainage and the geomorphic evolution of passive margins in Southwestern Australia, Z. Geomorphol., 47, 273-288, 2003

Bell, R. W., Schofield, N. J., Loh, I. C., and Bari, M. A.: Groundwater response to reforestation in the Darling Range of Western Australia, J. Hydrol., 115, 297-317, https://doi.org/10.1016/0022-1694(90)90211-F, 1990.

Bennett, D. and George, R. J.: Long term monitoring of groundwater levels at 24 sites in Western Australia shows that integrated farm forestry systems have little impact on salinity, in: 2nd In- ternational Salinity Forum: Salinity, water and society-global issues, local action, Adelaide, Australia, 2008.

Bennett, D. and Macpherson, D. K.: A history of salinity in Western Australia important (and some unimportant) dates, Technical memorandum 83/1, Update of: CSIRO, Division of Groundwater Research, Perth, Western Australia, 2002.

Beringer, J., Hutley, L. B., McHugh, I., Arndt, S. K., Campbell, D., Cleugh, H. A., Cleverly, J., Resco de Dios, V., Eamus, D. Evans, B., Ewenz, C., Grace, P., Griebel, A., Haverd, V., HinkoNajera, N., Huete, A., Isaac, P., Kanniah, K., Leuning, R., Liddell, M. J., Macfarlane, C., Meyer, W., Moore, C., Pendall, E., Phillips, A., Phillips, R. L., Prober, S. M., Restrepo-Coupe, N., Rutledge, S., Schroder, I., Silberstein, R., Southall, P., Yee, M. S., Tapper, N. J., van Gorsel, E., Vote, C., Walker, J., and Wardlaw, T.: An introduction to the Australian and New Zealand flux tower network - OzFlux, Biogeosciences, 13, 5895-5916, https://doi.org/10.5194/bg-13-5895-2016, 2016.

Bonell, M. and Williams, J. D.: A review of hydrology research within the open eucalypt woodlands of tropical semiarid Australia: A possible source of baseline information for the West African Sahel, Sécheresse, 20, 31-47, 2009.

Bowman, S. and Ruprecht, J. K.: Blackwood River flood risk study, Surface Water Hydrology, Science and Evaluation, Report: SWH 29, Water and Rivers Commission, Perth, Western Australia, 2000.

Bracken, L. J. and Croke, J. C.: The concept of hydrological connectivity and its contribution to understanding runoffdominated geomorphic systems, Hydrol. Process., 21, 17491763, https://doi.org/10.1002/hyp.6313, 2007.

Bracken, L. J., Wainwright, J., Ali, G. A., Tetzlaff, D., Smith, M. W., Reaney, S. M., and Roy, A. G.: Concepts of hydrological connectivity: Research approaches, pathways and future agendas, Earth-Sci. Rev., 119, 17-34, https://doi.org/10.1016/j.earscirev.2013.02.001, 2013.

Callow, J. N.: Understanding patterns of vegetation degradation at meaningful scales within saline landscapes, Ecohydrology, 4, 841-854, https://doi.org/10.1002/eco.190, 2011.

Callow, J. N.: Potential for vegetation-based river management in dryland, saline catchments, River Res. Appl., 28, 1072-1092, https://doi.org/10.1002/rra.1506, 2012.

Callow, J. N. and Clifton, J.: Globalised Agriculture, Development and the Environment, Globalisation, Agriculture and Development: Perspectives from the Asia-Pacific, edited by: Tonts, M. J. and Siddique, M. A. B., Elgar, UK, 2011.

Callow, J. N. and Smettem, K. R. J.: Channel response to a new hydrological regime in southwestern Australia, Geomorphology, 84, 254-276, https://doi.org/10.1016/j.geomorph.2006.01.043, 2007.

Callow, J. N., Van Niel, K. P., and Boggs, G. S.: How does modifying a DEM to reflect known hydrology affect subsequent terrain analysis?, J. Hydrol., 332, 30-39, https://doi.org/10.1016/j.jhydrol.2006.06.020, 2007.

Callow, J. N., Pope, T. I., and Coles, N. A.: Surface water flow redistribution processes: Toolibin Lake biodiversity recovery catchment, CER 07/01 - SESE129, Report by the ARWA - Centre for Ecohydrology for the Department of Environment and Conservation, Perth, Western Australia, 2008.

Callow, J. N. and Smettem, K. R. J.: The effect of farm dams and constructed banks on hydrologic connectivity and runoff estima- 
tion in agricultural landscapes, Environ. Model. Softw., 24, 959968, https://doi.org/10.1016/j.envsoft.2009.02.003, 2009.

Callow, J. N., Coles, N. A., and Hall, T. J.: A new ecohydraulic management paradigm for salt affected ecosystems and wetlands in low-gradient semi-arid environments, in: 8th International Symposium on Ecohydraulics (ISE), Seoul, Korea, 1596-1603, 2010.

Cattlin, T.: The impact of redistributed surface water and spatially distributed recharge on water quality decline in the Toolibin Lake catchment: a modelled approach to process management, MSc Thesis, National Centre for Groundwater Manegment, University of Technology, Sydney, 2006.

Cattlin, T. and Farmer, D.: Hydrological processes of the Wheatbelt region of Western Australia, in: Proceedings of the 13th International Soil Conservation Organisation Conference - Conserving Soil and Water for Society: Sharing Solutions ISCO 2004, Brisbane, Australia, 2004.

Cattlin, T., Stanton, D., Farmer, D. L., and Coles, N. A.: Surface water management strategy - Report for the Shire of Yilgarn, Technical Report, Engineering Water Management Group, Department of Agriculture Western Australia, South Perth, Western Australia, 2002.

Cattlin, T., Farmer, D. L., Coles, N. A., and Stanton, D.: Surface Water Assessment for the Toolibin Lake Recovery Catchment, Engineering Water Management Group, Department of Agriculture Western Australia, Perth, Australia, 2004.

Ceballos, A. and Schnabel, S.: Hydrological behaviour of a small catchmnet in the dehesa landuse system (Extremadura, SW Spain), J. Hydrol., 210, 146-160, 1998.

Clarke, J. D. A.: Evolution of the Lefroy and Cowan palaeodrainage channels, Westerm Australia, Aust. J. Earth Sci., 41, 55-68, 1994.

Coles, N. A., George, R. J., and Bathgate, A.: An assessment of the efficacy of deep drains construction in the wheatbelt of Western Australia, Agriculture Western Australia, Perth, Western Australia, 1999.

Coletti, J. Z., Hinz, C., Vogwill, R., and Hipsey, M. R.: Hydrological controls on carbon metabolism in wetlands, Ecol. Model., 249, 3-18, https://doi.org/10.1016/j.ecolmodel.2012.07.010, 2013.

Commander, P., Schoknecht, N., Verboom, B., and Caccetta, P. A.: The geology, physiography and soils of wheatbelt valleys, Dealing with salinity in Wheatbelt valleys: processes, prospects and practical options, Merredin, Western Australia, 2001,

Conacher, A. J.: Salt scalds and subsurface water: a special case of badland development in south-western Australia, in: Badland Geomorphology and Piping, edited by: Bryan, B. and Yair, A., Geo-Books, Norwich, 195-219, 1982.

Conacher, A. J. and Conacher, J.: Rural land degradation in Australia, Oxford University Press, Melbourne, 170 pp., 1995.

Conacher, A. J. and Sala, M.: Land degradation in Mediterranean environments of the world: nature and extent, causes and solutions, John Wiley and Sons, Chichester, 491 pp., 1998.

Costa, A. C., Foerster, S., de Araújo, J. C., and Bronstert, A.: Analysis of channel transmission losses in a dryland river reach in northeastern Brazil using streamflow series, groundwater level series and multi-temporal satellite data, Hydrol. Process., 27, 1046-1060, https://doi.org/10.1002/hyp.9243, 2012.

Cramer, V. A. and Hobbs, R. J.: Ecological consequences of altered hydrological regimes in fragmented ecosystems in southern Australia: Impacts and possible management responses, Aust. Ecol.,
27, 546-564, https://doi.org/10.1046/j.1442-9993.2002.01215.x, 2002.

Drake, P. L., Coleman, B. F., and Vogwill, R.: The response of semi-arid ephemeral wetland plants to flooding: linking water use to hydrological processes, Ecohydrology, 6, 852-862, https://doi.org/10.1002/eco.1309, 2013.

Dunkerley, D.: Effects of rainfall intensity fluctuations on infiltration and runoff: rainfall simulation on dryland soils, Fowlers Gap, Australia, Hydrol. Process., 26, 2211-2224, https://doi.org/10.1002/hyp.8317, 2011.

Eamus, D., Hatton, T., Cook, P., and Colvin, C.: Ecohydrology: Vegetation Function, Water and Resource Management, CSIRO Publishing, Canberra, 2006.

Farmer, D., Stanton, D., and Coles, N. A.: Surface Water Assessment and Recommendations for the Lake Bryde Recovery Catchment, Engineering Water Management Group, Department of Agriculture, South Perth, Western Australia, 2001.

Farmer, D., Stanton, D., and Coles, N. A.: Lake Bryde Recovery Catchment Surface Water Assessment and Recommendations, Engineering Water Management Group, Department of Agriculture Western Australia, Report prepared for the Department of Conservation and Land Management, Perth, Western Australia, 2002.

Ferdowsian, R., George, R., Lewis, F., McFarlane, D. J., Short, R., and Speed, R.: The extent of dryland salinity in Western Australia, in: 4th National Conference and Workshop on the Productive Use and Rehabilitation of Saline Lands (PURSL), Albany, Western Australia, 1996.

George, R.: Estimating and modifying the effects of agricultural development on the groundwater balance of large wheatbelt catchments, Western Australia, J. Appl. Hydrogeol., 1, 41-54, 1992.

George, R., and Conacher, A. J.: Mechanisms responsible for streamflow generation on a small, salt-affected and deeply weathered hillslope., Earth Surface Processes and Landforms, 18, 291-309, 1993.

George, R. J.: Reclaiming sandplain seeps by intercepting perched groundwater with eucalypts, Land Degrad. Dev., 2, 13-25, 1990.

George, R. J., Nulsen, R. A., Ferdowsian, R., and Raper, G. P.: Interactions between trees and groundwaters in recharge and discharge areas - A survey of Western Australian sites, Agr. Water Manage., 39, 91-113, 1999.

George, R. J., Speed, R. J., Simons, J. A., Smith, R. H., Ferdowsian, R., Raper, G. P., and Bennett, D.: Long-term groundwater trends and their impact on the future extent of dryland salinity in Western Australia in a variable climate, in: 2nd International Salinity Forum: Salinity, water and society-global issues, local action, Adelaide, Australia, 2008.

Ghassemi, F., Jakeman, A. J., and Nix, H. A.: Salinisation of land and water resources: human causes, extent, management and case studies, University of New South Wales Press, Syndey, Australia, 526 pp., 1995.

Gifford, G. F.: Rangeland hydrology in Australia - A brief review, Aust. Rangeland J., 1, 150-166, 1978.

Grayson, R., Argent, R. M., Nathan, R. J., McMahon, T. A., and Mein, R. G.: Hydrological recipes: Estimation techniques in Australian hydrology, Cooperative Research Centre for Catchment Hydrology, Monash University, Victoria, Australia, 125 pp., 1996. 
Halse, S. A., Ruprecht, J. K., and Pinder, A. M.: Salinisation and prospects for biodiversity in rivers and wetlands of south-west Western Australia, Aust. J. Bot., 51, 673-688, https://doi.org/10.1071/BT02113, 2003.

Hatton, T. J. and Nulsen, R. A.: Towards achieving functional ecosystem mimicry with respect to water cycling in southern Australian agriculture, Agroforest. Syst., 45, 203-214, 1999.

Hatton, T. and Salama, R. B.: Is it feasible to restore the salinityaffected rivers of the Western Australian wheatbelt?, in: Proceedings of Second Australian Stream Management Conference, Adelaide, 313-317, 1999.

Hatton, T. J., Ruprecht, J., and George, R. J.: Preclearing hydrology of the Western Australia wheatbelt: Target for the future?, Plant Soil, 257, 341-356, 2003.

HilleRisLambers, R., Rietkerk, M., van den Bosch, F., Prins, H. H. T., and de Kroon, H.: Vegetation pattern formation in semi-arid grazing systems, Ecology, 82, 50-61, https://doi.org/10.1890/00129658(2001)082[0050:vpfisa]2.0.co;2, 2001.

Hingston, F. J. and Gailitis, V.: The geographic variation of salt precipitated over Western Australia, Aust. J. Soil Res., 14, 319-335, 1976.

Hipsey, M. R., Vogwill, R., Farmer, D., and Busch, B. D.: A multiscale ecohydrological model for assessing floodplain wetland response to altered flow regimes, in: 19th International Congress on Modelling and Simulation, Perth, Australia, 2011.

Hrachowitz, M., Savenije, H. H. G., Blöschl, G., McDonnell, J. J., Sivapalan, M., Pomeroy, J. W., Arheimer, B., Blume, T., Clark, M. P., Ehret, U., Fenicia, F., Freer, J. E., Gelfan, A., Gupta, H. V., Hughes, D. A., Hut, R. W., Montanari, A., Pande, S., Tetzlaff, D., Troch, P. A., Uhlenbrook, S., Wagener, T., Winsemius, H. C., Woods, R. A., Zehe, E., and Cudennec, C.: A decade of Predictions in Ungauged Basins (PUB) - a review, Hydrolog. Sci. J., 58, 1198-1255, https://doi.org/10.1080/02626667.2013.803183, 2013.

Indian Ocean Climate Initiative: Climate variability and change in south Western Australia, Indian Ocean Climate Initiative, Perth, Western Australia, 2002.

Johnsen, C., George, R., Clarke, C., Harper, R., and Bren, L.: Groundwater Response To Partial Plantings On Discharge Zones At Five Sites In The South West Of Western Australia, in: Second International Salinity Forum, Adelaide, Australia, 2008.

Johnstone, M. H., Lowry, D. C., and Quilty, P. G.: The geology of southwestern Australia - a review, J. Roy. Soc. West. Aust., 56, $5-15,1973$.

Jones, C. E.: The Great Salinity Debate: Part 1 Controlling the salinisation process, Stipa Newsletter, 14, 4-6, 2000a.

Jones, C. E.: The Great Salinity Debate: Part 2 Why the rechargedischarge model is fundamentally flawed, Stipa Newsletter, 14, 6-11, 2000b.

Knighton, A. D. and Nanson, G. C.: An event-based approach to the hydrology of arid zone rivers in the Channel Country of Australia, J. Hydrol., 254, 102-123, https://doi.org/10.1016/S00221694(01)00498-X, 2001.

Koohafkan, P. and Stewart, B. A.: Drylands, people and land use, in: Water and Cereals in Drylands, edited by: Koohafkan, P. and Stewart, B. A., The Food and Agriculture Organization of the United Nations and Earthscan, London, 2008.
Ludwig, J. A. and Tongway, D. J.: Viewing rangelands as landscape systems, in: Rangeland desertification, edited by: Arnalds, O. and Archer, S., Kluwer Academic Publishers, Dordrecht, the Netherlands, 39-52, 2000.

Ludwig, J. A., Tongway, D. J., Freudenberger, D. O., Noble, J. C., and Hodgkinson, K. C.: Landscape ecology, function and management: principles from Australia's rangelands, CSIRO Publishing, Melbourne, Australia, 1997.

Ludwig, J. A., Wilcox, B. P., Breshears, D. D., Tongway, D. J., and Imeson, A. C.: Vegetation Patches and Runoff-Erosion as Interacting Ecohydrological Processes in Semiarid Landscapes, Ecology, 86, 288-297, https://doi.org/10.1890/03-0569, 2005.

Mann, E. A.: Does clearing increase salt in ground, J. Agricult. West. Aust., 15, 193, 1907.

McDonnell, J. J. and Woods, R.: On the need for catchment classification, J. Hydrol., 299, 2-3, https://doi.org/10.1016/j.jhydrol.2004.09.003, 2004.

McFarlane, D., Engel, R., and Ryder, A.: The location of recharge areas responsible for valley salinity in the Lake Toolibin Catchment, Western Australia, Groundwater Recharge, in: Symposium on Groundwater Recharge, Perth, Western Australia, 255-267, 1989.

McFarlane, D., Stone, R., Martens, S., Thomas, J., Silberstein, R., Ali, R., and Hodgson, G.: Climate change impacts on water yields and demands in south-western Australia, J. Hydrol., 475, 488-498, https://doi.org/10.1016/j.jhydrol.2012.05.038, 2012.

McGrath, G. S., Paik, K., and Hinz, C.: Microtopography alters self-organized vegetation patterns in water-limited ecosystems, J. Geophys. Res.-Biogeo., 117, G03021, https://doi.org/10.1029/2011jg001870, 2012.

McMillan, H. K., Clark, M. P., Bowden, W. B., Duncan, M., and Woods, R. A.: Hydrological field data from a modeller's perspective: Part 1. Diagnostic tests for model structure, Hydrol. Process., 25, 511-522, https://doi.org/10.1002/hyp.7841, 2011.

Mouat, N. C., George, R. J., Smettem, K. R. J., and Gilkes, R. J.: Identifying dominant catchment properties for predicting dryland salinity development in the Western Australian wheat belt, in: 2nd International Salinity Forum: Salinity, water and societyglobal issues, local action, Adelaide, Australia, 2008.

Muirden, P. and Coleman, S.: The Toolibin natural diversity recovery catchment review of surface water monitoring, Report for the Department of Parks and Wildlife, WA Government, Perth Western Australia, 2014.

Muirden, P., Pen, L., and Leybourne, M.: Stream and catchment hydrology in south west Western Australia, Report No. RR19, Department of Environment, Perth, Western Australia, 2003.

Mulcahy, M. J.: Landscapes, laterites and soils in southwestern Australia, in: Landform studies from Australia and New Guinea, edited by: Jennings, J. N. and Mabbutt, J. A., Australian National University Press, Canberra, 1967.

Nanson, G. C., Tooth, S., and Knighton, A. D.: A global perspective on dryland rivers: perceptions, misconceptions and distinctions, in: Dryland rivers: hydrology and geomorphology of semi-arid channels, edited by: Bull, L. J. and Kirkby, M. J., Wiley, Chichester, 17-54, 2002.

Nathan, E.: Giving Salt Some History, and History Some Salt: Dryland Salinity and the Dundas Tableland, Aust. Hist. Stud., 31, 222-236, https://doi.org/10.1080/10314610008596128, 2000. 
Nicolau, J. M., Solé-Benet, A., Puigdefábregas, J., and Gutiérrez, L.: Effects of soil and vegetation on runoff along a catena in semi-arid Spain, Geomorphology, 14, 297-309, https://doi.org/10.1016/0169-555x(95)00043-5, 1996.

Nielsen, D. L., Brock, M. A., Rees, G., N., and Baldwin, D. S.: Effects of increasing salinity on freshwater ecosystems in Australia, Aust. J. Bot., 51, 655-665, https://doi.org/10.1071/BT02115, 2003.

Nulsen, R. A.: Critical depth to saline groundwater in non-irrigated situations, Aust. J. Soil Res., 19, 83-86, https://doi.org/10.1071/SR9810083, 1981.

Nulsen, R. A. and Henschke, C. J.: Groundwater systems associated with secondary salinity in Western Australia, Agr. Water Manage., 4, 173-186, https://doi.org/10.1016/0378-3774(81)900494, 1981 .

Pannell, D.: Dryland salinity: economic, scientific, social and policy dimensions, Aust. J. Agricult. Resour. Econ., 45, 517-546, 2001.

Pannell, D.: Public Benefits, Private Benefits, and Policy Mechanism Choice for Land-Use Change for Environmental Benefits, Land Econ., 84, 225-240, 2008.

Pannell, D. and Ewing, M. A.: Managing secondary dryland salinity: Options and challenges, in: Proceedings 4th International Crop Science Congress, Brisbane, Australia, 2004.

Peck, A. J. and Hatton, T.: Salinity and the discharge of salts from catchments in Australia, J. Hydrol., 272, 191-202, 2003.

Pen, L. J.: Managing our rivers: a guide to the nature and management of the streams of south-west Western Australia, Water and Rivers Commission, East Perth, Western Australia, 1999.

Powell, D. M.: Dryland Rivers: Processes and Forms, in: Geomorphology of Desert Environments, edited by: Parsons, A. J. and Abrahams, A. D., Springer, Dordrecht, 333-373, 2009.

Ruprecht, J. K. and Schofield, N. J.: Analysis of streamflow generation following deforestation in southwestern Western Australia, J. Hydrol., 105, 1-17, 1989.

Ruprecht, J. K. and Schofield, N. J.: Effects of partial deforestation on hydrology and salinity in high salt storage landscapes. I. Extensive block clearing, J. Hydrol., 129, 19-38, 1991.

Ruprecht, J. K. and Stoneman, G. L.: Water yield issues in the jarrah forest of south-western Australia, J. Hydrol., 150, 369-391, 1993.

Ryan, J. G., McAlpine, C. A., Ludwig, J. A., and Callow, J. N.: Modelling the Potential of Integrated Vegetation Bands (IVB) to Retain Stormwater Runoff on Steep Hillslopes of Southeast Queensland, Australia, Land, 4, 711-736, 2015.

Smettem, K. and Callow, N.: Impact of Forest Cover and Aridity on the Interplay between Effective Rooting Depth and Annual Runoff in South-West Western Australia, Water, 6, 2539-2551, 2014.

Smettem, K. R. J., Waring, R. H., Callow, J. N., Wilson, M., and $\mathrm{Mu}, \mathrm{Q}$.: Satellite-derived estimates of forest leaf area index in southwest Western Australia are not tightly coupled to interannual variations in rainfall: implications for groundwater decline in a drying climate, Global Change Biol., 19, 2401-2412, https://doi.org/10.1111/gcb.12223, 2013.

Smith, I. N., McIntosh, P., Ansell, T. J., Reason, C. J. C., and McInnes, K.: Southwest Western Australian winter rainfall and its association with Indian Ocean climate variability, Int. J. Climatol., 20, 1913-1930, https://doi.org/10.1002/10970088(200012)20:15<1913::AID-JOC594>3.0.CO;2-J, 2000.
Stewart, B., Strehlow, K., and Davis, J.: Impacts of deep open drains on water quality and biodiversity of receiving waterways in the Wheatbelt of Western Australia, Hydrobiologia, 619, 103-118, https://doi.org/10.1007/s10750-008-9603-x, 2009.

Sturman, A. P. and Tapper, N. J.: The weather and climate of Australia and New Zealand, Oxford University Press, Melbourne, 1996.

Teakle, L. J. H. and Burvill, G. H.: The movement of soluble salts in soils under light rainfall conditions, J. Agricult. West. Aust., $15,218-245,1938$.

Thornes, J. B.: Catchment and Channel Hydrology, in: Geomorphology of Desert Environments, edited by: Parsons, A. J. and Abrahams, A. D., Springer Netherlands, 2009.

Tooth, S.: Process, form and change in dryland rivers: a review of recent research, Earth Sci. Rev., 51, 67-107, https://doi.org/10.1016/S0012-8252(00)00014-3, 2000.

Turnbull, L., Wilcox, B. P., Belnap, J., Ravi, S., D’Odorico, P., Childers, D., Gwenzi, W., Okin, G., Wainwright, J., Caylor, K. K., and Sankey, T.: Understanding the role of ecohydrological feedbacks in ecosystem state change in drylands, Ecohydrology, 5, 174-183, https://doi.org/10.1002/eco.265, 2012.

US Army Corps of Engineers: HEC-RAS River Systems Analysis User's Manual, Hydrologic Engineering Center, Institute of Water Resources, US Army Corps of Engineers, Davis, 2008

van de Graaff, W. J. E., Crowe, R. W. A., Bunting, J. A., and Jackson, M. J.: Relict Early Cainozoic drainages in arid Western Australia, Z. Geomorphol., 21, 379-400, 1977.

Verboom, W.: Soils of the Toolibin Lake Catchment, Agriculture Western Australia, Perth, Australia, 2003.

Wagener, T., Sivapalan, M., Troch, P., and Woods, R.: Catchment Classification and Hydrologic Similarity, Geogr. Compass, 1, 901-931, https://doi.org/10.1111/j.1749-8198.2007.00039.x, 2007.

Walker, K. F., Sheldon, F., and Puckridge, J. T.: A perspective on dryland river ecosystems, Regulat. Rivers: Res. Manage., 11, 85104, 1995.

Wang, L., D’Odorico, P., Evans, J. P., Eldridge, D. J., McCabe, M. F., Caylor, K. K., and King, E. G.: Dryland ecohydrology and climate change: critical issues and technical advances, Hydrol. Earth Syst. Sci., 16, 2585-2603, https://doi.org/10.5194/hess-162585-2012, 2012.

Watson, A. N.: The clearing history of the Toolibin area and some of its effects, Compliled for the Northern Arthur River Rehabilitation Committee, Unpublished Report to the State Minister of Fisheries and Wildlife, Perth, Western Australia, 1978.

Wilcox, B. P. and Newman, B. D.: Ecohydrology of Semiarid Landscapes, Ecology, 86, 275-276, https://doi.org/10.1890/04-0631, 2005.

Wood, W. E.: Increase of salt in soil and streams following the destruction of the native vegetation, J. Roy. Soc. West. Aust., 10, 35-47, 1924.

Wood, W. E. and Wilsmore, N. T. M.: Salinity of rain in Western Australia, J. Roy. Soc. West. Aust., 15, 22-30, 1928. 